\title{
Thermal Properties of Mixed Alkali Bis(trifluoromethylsulfonyl)amides
}

$\operatorname{AUTHOR}(S)$ :

Hagiwara, Rika; Tamaki, Kenichiro; Kubota, Keigo; Goto, Takuya; Nohira, Toshiyuki

\section{CITATION:}

Hagiwara, Rika ...[et al]. Thermal Properties of Mixed Alkali

Bis(trifluoromethylsulfonyl)amides. Journal of Chemical \& Engineering Data 2008, 53(2): 355-358

\section{ISSUE DATE:}

2008-02-01

URL:

http://hdl.handle.net/2433/260916

\section{RIGHT:}

This document is the Accepted Manuscript version of a Published Work that appeared in final form in Journal of Chemical \& Engineering Data, copyright $\odot$ American Chemical Society after peer review and technical editing by the publisher. To access the final edited and published work see https://doi.org/10.1021/je700368r.; This is not the published version. Please cite only the published version.; この論文は出版社版でありません。引用の際には出版社版 をご確認ご利用ください。 


\section{Thermal properties of mixed alkali bis(trifluoromethylsulfonyl)amides}

Rika Hagiwara, Kenichiro Tamaki, Keigo Kubota, Takuya Goto, Toshiyuki Nohira

Graduate School of Energy Science, Kyoto University

Sakyo-ku, Kyoto 606-8501, Japan

Phase diagrams of binary mixtures of alkali bis(trifluoromethylsulfonyl)amides

have been constructed and their eutectic compositions and temperatures have been determined. It has been revealed that the molten salt electrolytes having the melting points in the intermediate temperature range (373 to 473) K are easily formed by simple mixing of two kinds of single alkali bis(trifluoromethylsulfonyl)amides salts. The 1:1 or 3:1 double salt is occasionally formed for some binary systems. 


\section{Introduction}

Molten salts have excellent characteristics as electrolytes such as negligibly small volatility, non-flammability, high electrochemical stability and high ionic conductivity $^{1-2}$. Molten salts are roughly classified into two groups: high temperature molten salts ( $T>673 \mathrm{~K}$ ) and room (or ambient) temperature molten salts ( $T<373 \mathrm{~K}$ ). There is a trade-off between the features as electrolytes for the high temperature and room temperature molten salts. High temperature molten salts are generally superior in physicochemical properties such as high conductivities, wide electrochemical windows and wide liquid temperature range. On the other hand, the room temperature molten salts, also called ionic liquids, have the advantages of an easy handling and wide range of application field ${ }^{3-6}$. Salts consisting of alkali metal cations and bis(trifluoromethylsulfonyl)amide $\left(\mathrm{Tf}_{2} \mathrm{~N}\right)$ anion, $\mathrm{MTf}_{2} \mathrm{~N}(\mathrm{M}=\mathrm{Li}, \mathrm{Na}, \mathrm{K}, \mathrm{Rb}, \mathrm{Cs})$ are solids at room temperature, but have, or are expected to have, melting points at relatively low temperatures ${ }^{7-8}$. The $\mathrm{Tf}_{2} \mathrm{~N}$ anion is well known as one of the major anions constituting room temperature molten salts because of its high chemical and electrochemical stability ${ }^{9}$. 
It would be possible to obtain molten salts having melting points of lower than those of the single $\mathrm{MTf}_{2} \mathrm{~N}$ salts from their mixture. These molten salt mixtures are expected to have melting points from (373 to 473) $\mathrm{K}$ and be used at intermediate temperatures (373 to 673) K, giving averaged characteristics of high temperature and room temperature molten salts. It is also expected that the alkali metal $\mathrm{Tf}_{2} \mathrm{~N}$ salts are promising as intermediate temperature molten salt electrolytes for electrochemical systems including a process of alkali metal depositions owing to the high electrochemical stability of $\mathrm{Tf}_{2} \mathrm{~N}$ anion. For example, lithium metal is expected to deposit at the cathode limit of mixed $\mathrm{MTf}_{2} \mathrm{~N}$ molten salts containing $\operatorname{LiTf}_{2} \mathrm{~N}$ and these molten salts are able to be used as electrolytes for lithium ion batteries operating at intermediate temperatures.

Many researchers have reported organic electrolytes for lithium ion batteries in which $\mathrm{LiTf}_{2} \mathrm{~N}$ is dissolved as supporting electrolytes ${ }^{10-12}$, however, the properties reported for $\mathrm{MTf}_{2} \mathrm{~N}$ salts themselves are limited except for some crystal structures ${ }^{13}$. No reports are available on the physicochemical properties of the molten $\mathrm{MTf}_{2} \mathrm{~N}$ salts and their mixtures.

In this study, the thermal properties of the mixtures of the two $\mathrm{MTf}_{2} \mathrm{~N}$ single salts $(\mathrm{M}=\mathrm{Li}, \mathrm{Na}, \mathrm{K}, \mathrm{Rb}, \mathrm{Cs})$ were systematically investigated to construct phase 
diagrams and determine the composition giving the melting points in the intermediate temperature range.

\section{Experimental Section}

Bis(trifluoromethylsulfonyl)imide, $\mathrm{HTf}_{2} \mathrm{~N}$ (Morita Chemical Industries, purity $>99 \%$ ), $\mathrm{Na}_{2} \mathrm{CO}_{3}$ (Wako Pure Chemical Industries, purity > $99.5 \%$ ), $\mathrm{K}_{2} \mathrm{CO}_{3}$ (Wako Pure Chemical Industries, purity $99.9 \%$ ), $\mathrm{Rb}_{2} \mathrm{CO}_{3}$ (Wako Pure Chemical Industries, purity $99.9 \%$ ) and $\mathrm{Cs}_{2} \mathrm{CO}_{3}$ (Aldrich, purity $99.9 \%$ ) were used for the syntheses of $\mathrm{MTf}_{2} \mathrm{~N}$ salts. $\mathrm{LiTf}_{2} \mathrm{~N}$ (Morita Chemical Industries, purity > $99.0 \%$ ) was used as received. Melting points and thermal decomposition temperatures of single $\mathrm{MTf}_{2} \mathrm{~N}$ salts were measured by means of differential scanning calorimetry (DSC) and thermogravimetry (TG), respectively. Temperature was increased with a scan rate of 10 $\mathrm{K} \min ^{-1}$. The phase diagrams of the binary $\mathrm{MTf}_{2} \mathrm{~N}$ salt mixtures were constructed by plotting the temperatures of endothermic peaks found on the DSC curves obtained in the heating process against the compositions of the salts. The transition temperatures were determined in heating process in order to avoid uncertainty by supercooling. The liquidus and solidus curves were drawn by eye through experimental plots. The 
measurements were performed for the rate $5 \%$. Aluminum pans were used for the sample holders. Prior to the measurements, the sample was melted at $573 \mathrm{~K}$ in order to prepare homogenous samples. The measurement was started after cooling the pre-treated samples down to room temperature. In this study, accuracy of melting points $\underline{\text { is } \pm 5 \mathrm{~K}}$.

\section{Results and discussion}

Melting and thermal decomposition temperatures of single $\mathrm{MTf}_{2} \mathrm{~N}$ salts

The melting and thermal decomposition temperatures of $\mathrm{MTf}_{2} \mathrm{~N}$ single salts in this study are summarized in Table 1 . Figure 1 shows the plots of the melting points of the single salts against the reciprocal radii of the cations. Coordination numbers of the cations $\left(\operatorname{LiTf}_{2} \mathrm{~N}:\right.$ 6, $\mathrm{NaTf}_{2} \mathrm{~N}:$ 6, $\mathrm{KTf}_{2} \mathrm{~N}: 8 \mathrm{RbTf}_{2} \mathrm{~N}:$ 8, $\left.\mathrm{CsTf}_{2} \mathrm{~N}: 10\right)$ from the previous study on the crystal structure of the $\mathrm{MTf}_{2} \mathrm{~N}$ salts ${ }^{13}$ are used to estimate the ionic radii of the cations. The melting point of the salt containing a smaller cation is generally higher, but it is found from the figure that the melting point of $\operatorname{LiTf}_{2} \mathrm{~N}$ does not follow the trend, irregularly lower than that of $\mathrm{NaTf}_{2} \mathrm{~N}$. This would be caused by the difference of the 
lattice energies of the salts with different structures containing a large organic anion in which the electrostatic interactions are more complicated than that in simple inorganic salts. The single $\mathrm{MTf}_{2} \mathrm{~N}$ salts are thermally stable to $700 \mathrm{~K}$ except for $\mathrm{LiTF}_{2} \mathrm{~N}$ of which the decomposition temperature is $657 \mathrm{~K}$. Thermal stability becomes higher with the increase of the size of the cation.

Phase diagrams of the binary $\mathrm{MTf}_{2} \mathrm{~N}$ salt mixtures

Figure 2 shows a phase diagram of $\operatorname{LiTf}_{2} \mathrm{~N}+\mathrm{NaTf}_{2} \mathrm{~N}$ binary system that exhibits a simple binary eutectic system. Figure 3 shows a phase diagram of $\mathrm{NaTf}_{2} \mathrm{~N}+$ $\mathrm{RbTf}_{2} \mathrm{~N}$ binary system. The phase diagram is also a simple eutectic type. No binary compounds and structural phase transition are observed. These two systems are a simple eutectic type in the binary $\mathrm{MTf}_{2} \mathrm{~N}$ systems examined here.

Figure 4 shows a phase diagram of $\mathrm{KTf}_{2} \mathrm{~N}+\mathrm{CsTf}_{2} \mathrm{~N}$. There are two endothermic peaks on the DSC curves at different temperatures at $\mathrm{X}_{\mathrm{KTf2N}} \geq 0.25$. Although only one peak is observed at $X_{K T f 2 N} \leq 0.20$, the system is considered to be a simple eutectic type. It is considered that the eutectic composition is very close to the $\mathrm{CsTf}_{2} \mathrm{~N}$ side, and that the eutectic temperature is almost equal to the melting point of 


\section{$\underline{\mathrm{CsTf}_{2} \mathrm{~N}}$.}

Figure 5 illustrates a phase diagram of $\operatorname{LiTf}_{2} \mathrm{~N}+\mathrm{RbTf}_{2} \mathrm{~N}$ system. The endothermic peak found at the lowest temperature, $421 \mathrm{~K}$, shifts by $5 \mathrm{~K}$ to a higher temperature, $426 \mathrm{~K}$, at $\mathrm{X}_{\mathrm{LiTf2N}}>0.50$. At this composition, only one endothermic peak is observed at $432 \mathrm{~K}$. This suggests the existence of a double salt, $\operatorname{LiRb}\left(\mathrm{Tf}_{2} \mathrm{~N}\right)_{2}$. As a result, this binary system has two eutectic points. A similar phase diagram is found for $\mathrm{LiTF}_{2} \mathrm{~N}-\mathrm{CsTF}_{2} \mathrm{~N}$ binary system as shown in Figure 6 . The endothermic peak at $385 \mathrm{~K}$ appears only at the compositions where the molar ratios of $\operatorname{LiTf}_{2} \mathrm{~N}$ are 0.05 to 0.50 and this peak disappears for the higher $\operatorname{LiTf}_{2} \mathrm{~N}$ compositions. This suggests the existence of a double salt, $\operatorname{LiCs}\left(\mathrm{Tf}_{2} \mathrm{~N}\right)_{2}$. As a result, this binary system has two eutectic points in common with the $\operatorname{LiTf}_{2} \mathrm{~N}+\mathrm{RbTf}_{2} \mathrm{~N}$. Formation of 1:1 double salts is suggested for these two systems.

A phase diagram of $\mathrm{LiTf}_{2} \mathrm{~N}+\mathrm{KTf}_{2} \mathrm{~N}$ binary system is shown in Figure 7. Two endothermic peaks are observed when the molar ratio of $\operatorname{LiTf}_{2} \mathrm{~N}$ exceeds 0.75 . These observations suggest the existence of the $3: 1$ double salt, $\mathrm{Li}_{3} \mathrm{~K}\left(\mathrm{TF}_{2} \mathrm{~N}\right)_{4}$. A peritectic point should exist at $\mathrm{X}_{\mathrm{LiTf2N}} \simeq 0.7$ with the temperature of $435 \mathrm{~K}$. The eutectic point is found at $\mathrm{X}_{\mathrm{LiTf2N}}=0.43$ with the temperature of $423 \mathrm{~K}$. A similar phase diagram is obtained for $\mathrm{NaTf}_{2} \mathrm{~N}+\mathrm{KTf}_{2} \mathrm{~N}$ binary system and shown in Figure 8. There is a 
peritectic point at $\mathrm{X}_{\mathrm{NaTf2N}}=0.45$ at a temperatures of $462 \mathrm{~K}$. Three endothermic peaks also appear at $\mathrm{X}_{\mathrm{NaTf2N}} \geq 0.45$. Similarly, it suggests the formation of a 3:1 double salt, $\mathrm{Na}_{3} \mathrm{~K}\left(\mathrm{Tf}_{2} \mathrm{~N}\right)_{4}$. Figure 9 illustrates a phase diagram of $\mathrm{NaTf}_{2} \mathrm{~N}+\mathrm{CsTf}_{2} \mathrm{~N}$. The endothermic peak at $383 \mathrm{~K}$ disappears at $\mathrm{X}_{\mathrm{NaTf2N}} \geq 0.75$. It suggests the formation of a 3:1 double salt, $\mathrm{Na}_{3} \mathrm{Cs}\left(\mathrm{Tf}_{2} \mathrm{~N}\right)_{4}$. A peritectic point is found at $\mathrm{X}_{\mathrm{NaTf2N}}=0.22$ with the temperature of $411 \mathrm{~K}$.

Table 2 summarizes the eutectic compositions and temperatures of binary $\mathrm{MTf}_{2} \mathrm{~N}$ salt mixtures. Table 3 summarizes the intermediate compounds of binary $\mathrm{MTf}_{2} \mathrm{~N}$ salt mixtures.

In the case of $\mathrm{KTf}_{2} \mathrm{~N}+\mathrm{RbTf}_{2} \mathrm{~N}$ binary system, as shown in Fig. 10, only one endothermic peak is observed for entire compositions in the DSC curves. It is, thus, impossible to obtain the compositions having lower melting point than neat $\mathrm{RbTf}_{2} \mathrm{~N}$ by the mixing of $\mathrm{KTf}_{2} \mathrm{~N}$ and $\mathrm{RbTf}_{2} \mathrm{~N}$. The $\mathrm{RbTf}_{2} \mathrm{~N}+\mathrm{CsTf}_{2} \mathrm{~N}$ system, as shown in Figure 11, is similar to the $\mathrm{KTf}_{2} \mathrm{~N}-\mathrm{RbTf}_{2} \mathrm{~N}$ system. In this binary system, again there is only one endothermic peak at different temperatures for all mole fractures. It is concluded that these two systems form solid solutions for all mole fractures. In these systems, it is considered that there are two-phase regions where liquid and solid solution exist between liquidus and solidus. However the regions could not be detected in this 
measurement.

It is found that the melting points are not lowered in the case of $\mathrm{KTf}_{2} \mathrm{~N}+$ $\mathrm{RbTf}_{2} \mathrm{~N}, \mathrm{KTF}_{2} \mathrm{~N}+\mathrm{CsTF}_{2} \mathrm{~N}$ and $\mathrm{RbTf}_{2} \mathrm{~N}+\mathrm{CsTf}_{2} \mathrm{~N}$ binary systems in which the two of the three heaviest alkali metal salts are mixed. When the cation sizes are close (K: 1.51 $\AA$, Rb: $1.61 \AA$, Cs: $1.81 \AA$ ), the binary salt system might behave as a pseudo single phase although the melting temperature shifts with the composition.

\section{Conclusions}

Thermal properties of the binary $\mathrm{MTf}_{2} \mathrm{~N}(\mathrm{M}=\mathrm{Li}, \mathrm{Na}, \mathrm{K}, \mathrm{Rb}, \mathrm{Cs})$ salt mixtures were investigated. Ten binary phase diagrams have been constructed. In the cases of the seven binary salt mixtures, the melting points are lowered to intermediate temperatures (373 to 473) $\mathrm{K}$ by the mixing of two single $\mathrm{MTf}_{2} \mathrm{~N}$ salts. Thus the mixing of alkali metal $\mathrm{Tf}_{2} \mathrm{~N}$ salt is an effective way to lower the melting temperature of alkali metal $\mathrm{Tf}_{2} \mathrm{~N}$ salts except for a few combinations. 
Literature Cited

(1) Ito, Y.; Nohira, T. Non-conventional Electrolytes for Electrochemical Applications.

Electrochim. Acta 2000, 45, 2611-2622.

(2) Galasiu, I.; Galasiu, R.; Thonstad, J. Electrochemistry of Molten Salts, In

Nonaqueous Electrochemistry, Chapt. 9, Aurbach, D. ed.; Marcel Dekker, New York, 1999; pp 461-591.

(3) Ionic Liquids in Synthesis. Holbrey, J.D.; Rogers, R. D. eds.; VCH-Wiley, Weinheim, 2002.

(4) Green Industrial Applications of Ionic Liquids. Rogers, R.D.; Seddon, K.R.; Volkov, S. eds.; Kluwer Academic Publishers, 2003.

(5) Electrochemical Aspects of Ionic Liquids. Ohno, H.ed.; John Wiley \& Sons, Inc., 2005.

(6) Hagiwara, R.; Lee, J, S. Ionic Liquids for Electrochemical Devices. Electrochemistry 2007, 75, 23-34.

(7) Lascaud, S.; Perrier, M.; Vallée, A.; Besner, S.; Prud’homme’, J.; Armand, J. Phase Diagrams and Conductivity Behavior of Poly(Ethylene Oxide)-Molten Salt Rubbery Electrolytes. Macromolecules 1994, 27, 7469-7477. 
(8) Foropoulos, J.; DesMarteau, D. D. Synthesis, Properties, and Reactions

Bis((trifluoromethyl)sulfonyl)Imide, $\left(\mathrm{CF}_{3} \mathrm{SO}_{2}\right)_{2} \mathrm{NH}$. Inorg. Chem. 1984, 23, 3720-3723.

(9) Bonhôte, P.;Dias, A-P.; Armand, M.; Papageorgiou, N.; Kalyanasundaram, K.;

Grätzel, M. Hydrophobic, Highly Conductive Ambient-Temperature Molten Salts.

Inorg. Chem. 1996, 35, 1168-1178.

(10) Matsumoto, H.; Yanagida, M.;Tanimoto, K.; Kojima, T.; Tamiya, Y.; Miyazaki, Y. Improvement of Ionic Conductivity of Room Temperature Molten Salt Based on Quaternary Ammonium Cation and Imide Anion. Proceedings - Electrochemical Society 2000, 99-41, 186-192.

(11) Koura, N.; Etoh, K.; Idemoto, Y.; Matsumoto, F. Electrochemical Behavior of Graphite-Lithium Intercalation Electrode in $\mathrm{AlCl}_{3}$-EMIC-LiCl-SOCl 2 Room-Temperature Molten Salt. Chemistry Letters 2001, 1320-1321.

(12) Sakaebe, H.; Matsumoto, H. $\quad N$-Methyl- $N$-Propylpiperidinium Bis(Trifluoromethanesulfonyl)Imide (PP13-TFSI) - Novel Electrolyte Base for Li Battery. Electrochemistry Communications 2003, 5, 594-598.

(13) Xue, L.; Padgett, C. W.; DesMarteau, D. D.; Pennington, W.T. Synthesis and Structures of Alkali Metal Salts of Bis[(Trifluoromethyl)sulfonyl]Imide. Solid State Sciences 2002, 4, 1535-1545. 
Table 1. Melting temperature $T$, and decomposition temperatures $T_{\mathrm{d}}$, of $\mathrm{MTf}_{2} \mathrm{~N}$ single salts.

\begin{tabular}{cccccc}
\hline & $\mathrm{LiTf}_{2} \mathrm{~N}$ & $\mathrm{NaTf}_{2} \mathrm{~N}$ & $\mathrm{KTf}_{2} \mathrm{~N}$ & $\mathrm{RbTf}_{2} \mathrm{~N}$ & $\mathrm{CsTf}_{2} \mathrm{~N}$ \\
\hline $\begin{array}{c}T / \mathrm{K} \\
\text { (this study) }\end{array}$ & 506 & 530 & 472 & 450 & 395 \\
\hline $\begin{array}{c}T / \mathrm{K} \\
\text { (previous study) }\end{array}$ & $507^{[7]}$ & - & $478^{[7]}$ & - & $388^{[8]}$ \\
\hline$T_{\mathrm{d}} / \mathrm{K}$ & $657^{[7]}$ & $714^{2}$ & 733 & 740 & 745 \\
\hline
\end{tabular}


Table 2. Eutectic compositions, $x_{\mathrm{eu}}$ and temperatures, $T_{\text {eu }}$ of the binary $\mathrm{MTf}_{2} \mathrm{~N}$ salt mixtures.

\begin{tabular}{rcc}
\hline System & $x_{\text {eu }}$ & $T_{\text {eu }} / \mathrm{K}$ \\
\hline $\operatorname{LiTf}_{2} \mathrm{~N}+\mathrm{NaTf}_{2} \mathrm{~N}$ & $x_{\text {LiTf2N }}=0.67$ & 453 \\
$\operatorname{LiTf}_{2} \mathrm{~N}+\mathrm{KTf}_{2} \mathrm{~N}$ & $x_{\text {LiTf2N }}=0.43$ & 423 \\
$\mathrm{KTf}_{2} \mathrm{~N}+\mathrm{CsTf}_{2} \mathrm{~N}$ & - & 395 \\
$\operatorname{LiTf}_{2} \mathrm{~N}+\mathrm{RbTf}_{2} \mathrm{~N}$ & $x_{\text {LiTf2N }}=0.25$ & 421 \\
& $=0.60$ & 426 \\
$\operatorname{LiTf}_{2} \mathrm{~N}+\mathrm{CsTf}_{2} \mathrm{~N}$ & $x_{\text {LiTf2N }}=0.07$ & 385 \\
& $=0.60$ & 432 \\
$\operatorname{NaTf}_{2} \mathrm{~N}+\mathrm{KTf}_{2} \mathrm{~N}$ & $x_{\mathrm{NaTf2N}}=0.25$ & 456 \\
$\operatorname{NaTf}_{2} \mathrm{~N}+\mathrm{RbTf}_{2} \mathrm{~N}$ & $x_{\mathrm{NaTf2N}}=0.25$ & 431 \\
$\operatorname{NaTf}_{2} \mathrm{~N}+\mathrm{CsTf}_{2} \mathrm{~N}$ & $x_{\text {NaTf2N }}=0.07$ & 383
\end{tabular}

Table 3. Intermediate compounds of the binary $\mathrm{MTf}_{2} \mathrm{~N}$ salt mixtures.

\begin{tabular}{cl}
\hline \multicolumn{1}{c}{ System } & Compound \\
\hline $\operatorname{LiTf}_{2} \mathrm{~N}+\mathrm{RbTf}_{2} \mathrm{~N}$ & $\mathrm{LiRb}\left(\mathrm{Tf}_{2} \mathrm{~N}\right)_{2}$ \\
\hline $\mathrm{LiTf}_{2} \mathrm{~N}+\mathrm{CsTf}_{2} \mathrm{~N}$ & $\mathrm{LiCs}\left(\mathrm{Tf}_{2} \mathrm{~N}\right)_{2}$ \\
$\mathrm{LiTf}_{2} \mathrm{~N}+\mathrm{KTf}_{2} \mathrm{~N}$ & $\mathrm{Li}_{3} \mathrm{~K}\left(\mathrm{Tf}_{2} \mathrm{~N}\right)_{4}$ \\
$\mathrm{NaTf}_{2} \mathrm{~N}+\mathrm{KTf}_{2} \mathrm{~N}$ & $\mathrm{Na}_{3} \mathrm{~K}\left(\mathrm{Tf}_{2} \mathrm{~N}\right)_{4}$ \\
$\mathrm{NaTf}_{2} \mathrm{~N}+\mathrm{CsTf}_{2} \mathrm{~N}$ & $\mathrm{Na}_{3} \mathrm{Cs}\left(\mathrm{Tf}_{2} \mathrm{~N}\right)_{4}$ \\
\hline
\end{tabular}




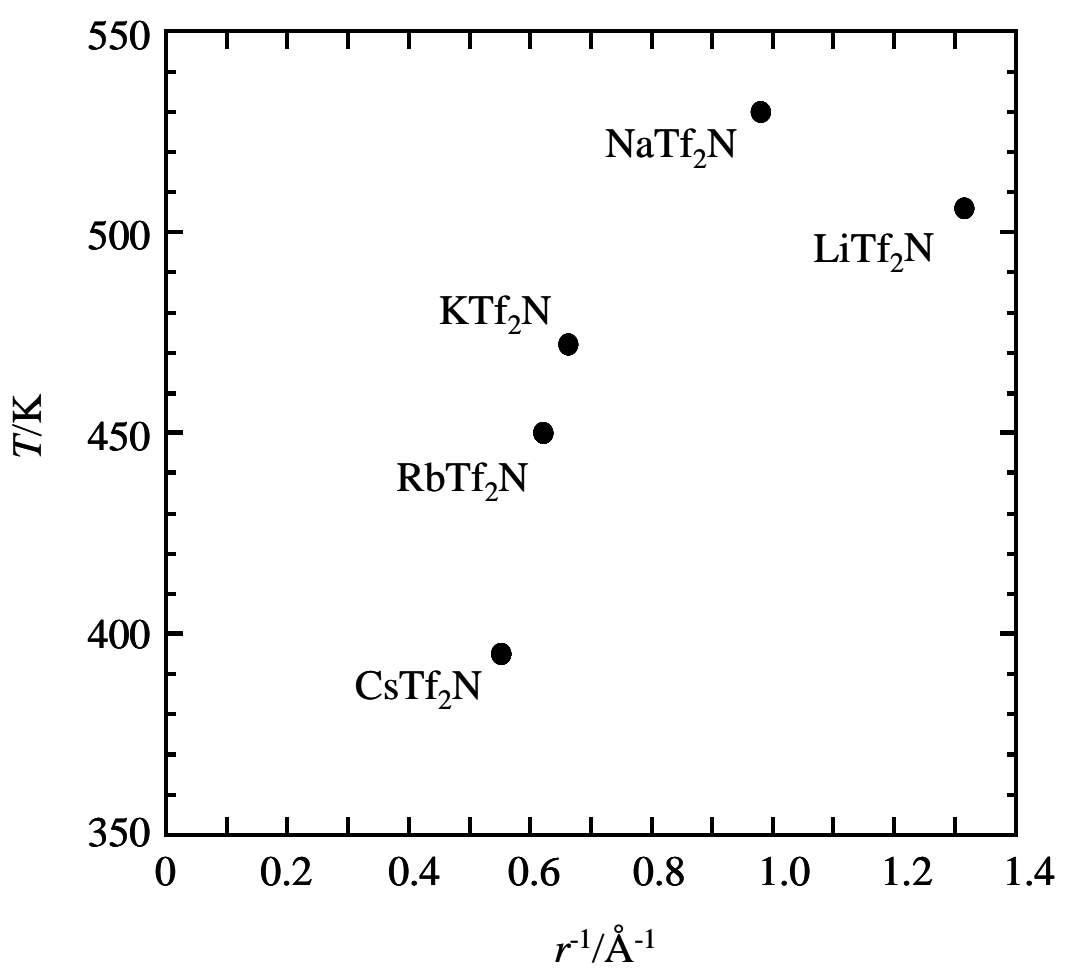

Figure 1. Plots of the melting temperature, $T$ against the reciprocal radius of the cations of the salts, $r$. 


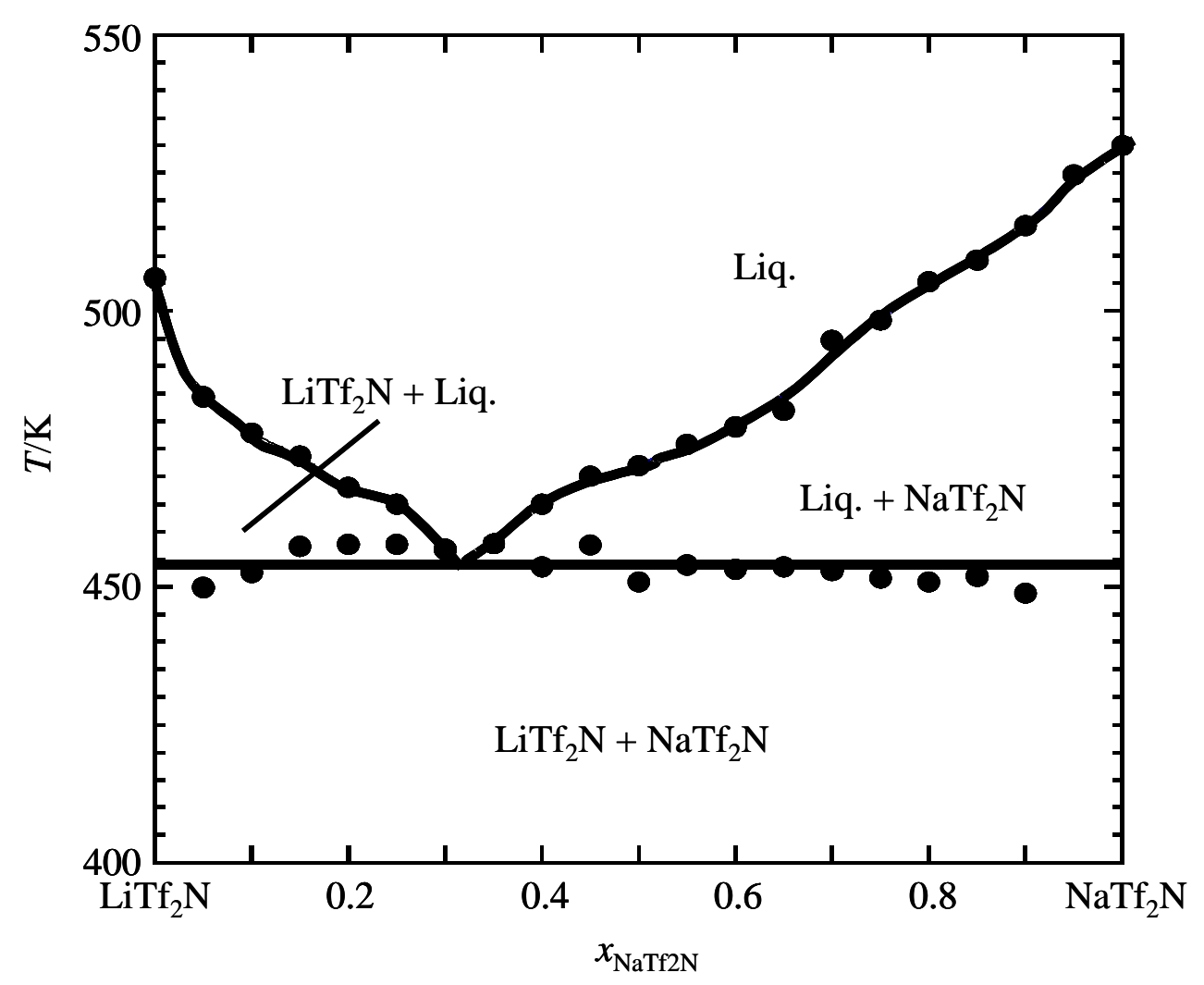

Figure 2. Phase diagram of $\mathrm{LiTf}_{2} \mathrm{~N}+\mathrm{NaTf}_{2} \mathrm{~N}$ 


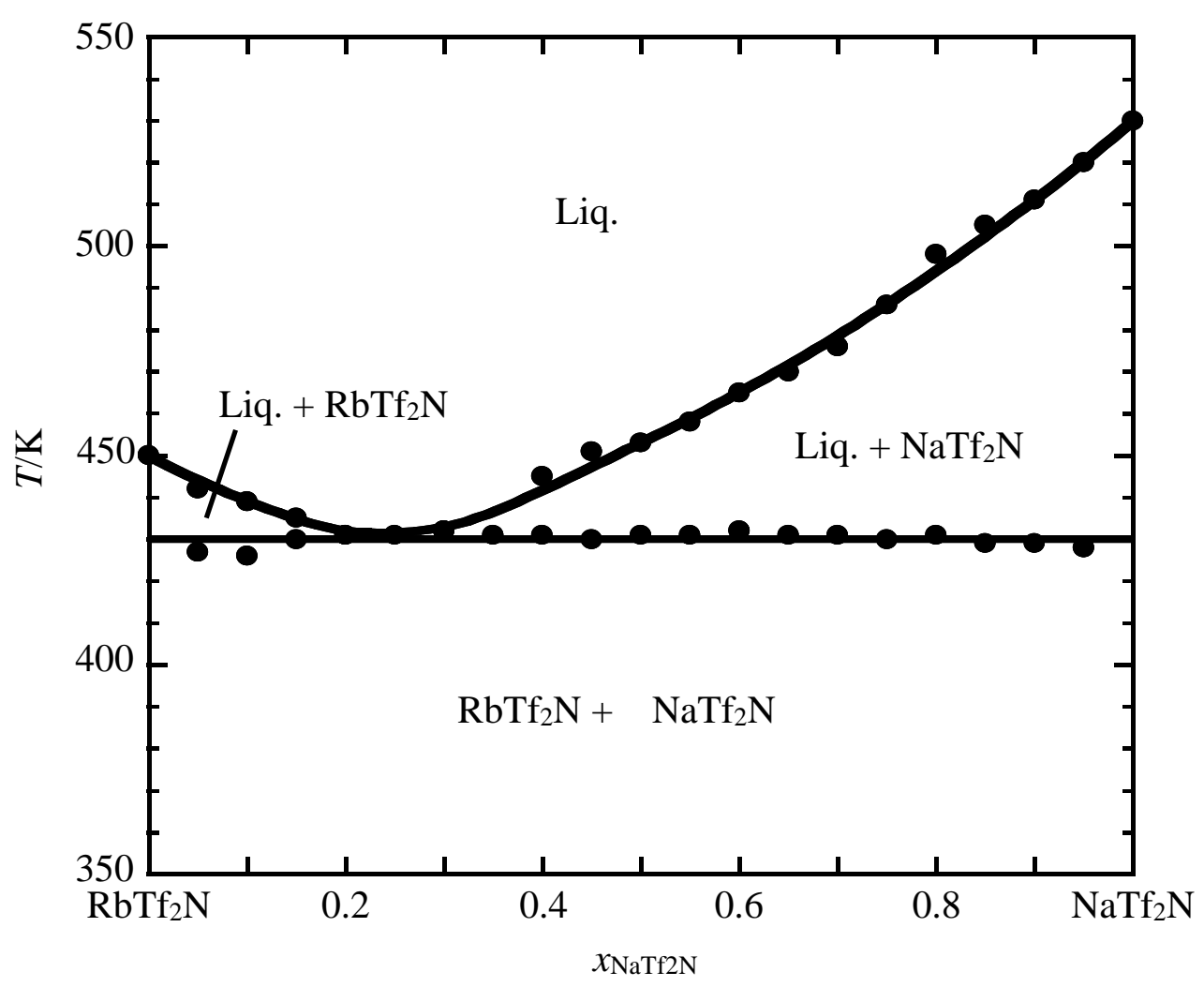

Figure 3. Phase diagram of $\mathrm{NaTf}_{2} \mathrm{~N}+\mathrm{RbTf}_{2} \mathrm{~N}$. 


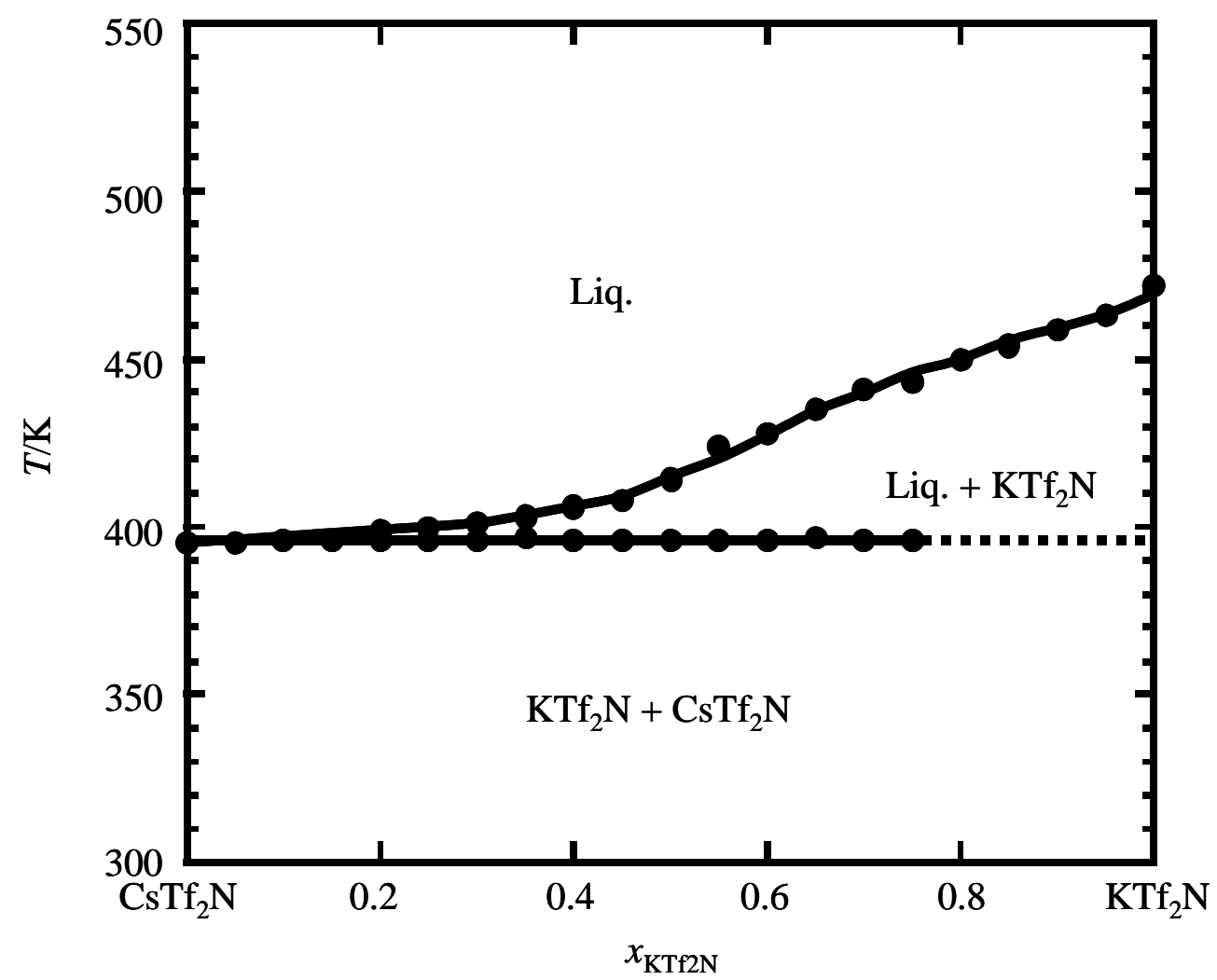

Figure 4. Phase diagram of $\mathrm{KTf}_{2} \mathrm{~N}+\mathrm{CsTf}_{2} \mathrm{~N}$. 


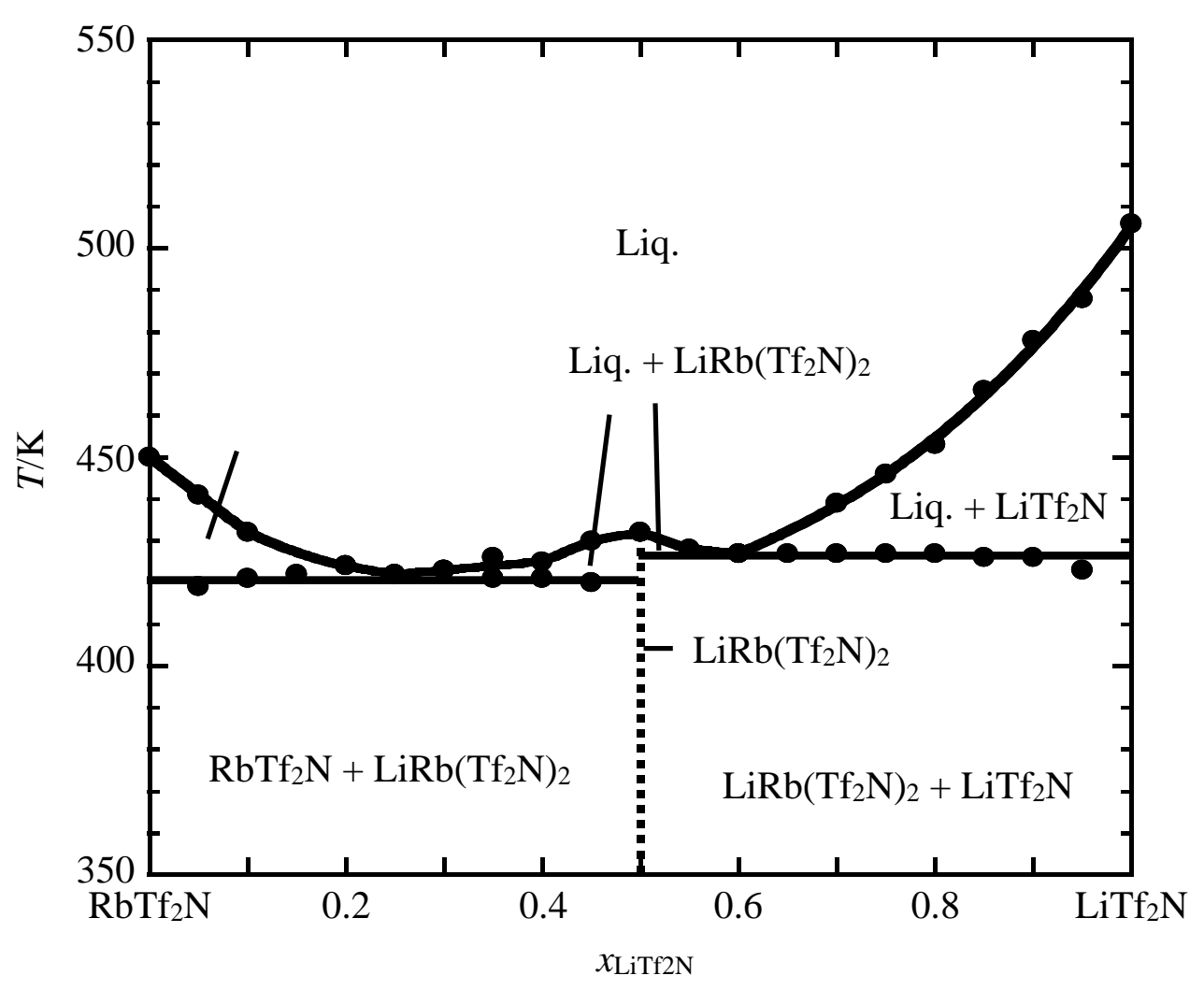

Figure 5. Phase diagram of $\operatorname{LiTf}_{2} \mathrm{~N}+\mathrm{RbTf}_{2} \mathrm{~N}$. 


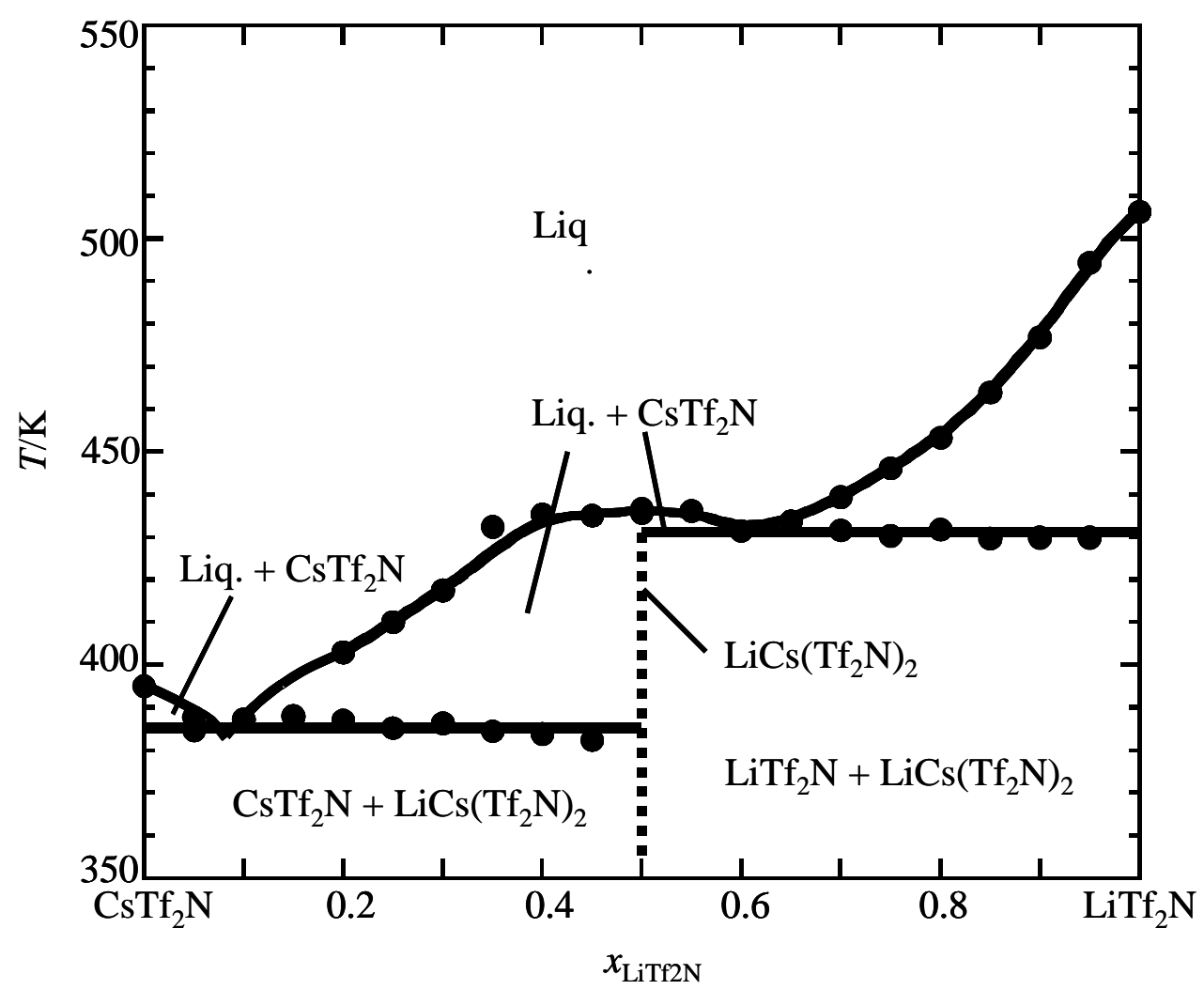

Figure 6. Phase diagram of $\mathrm{LiTf}_{2} \mathrm{~N}+\mathrm{CsTf}_{2} \mathrm{~N}$. 


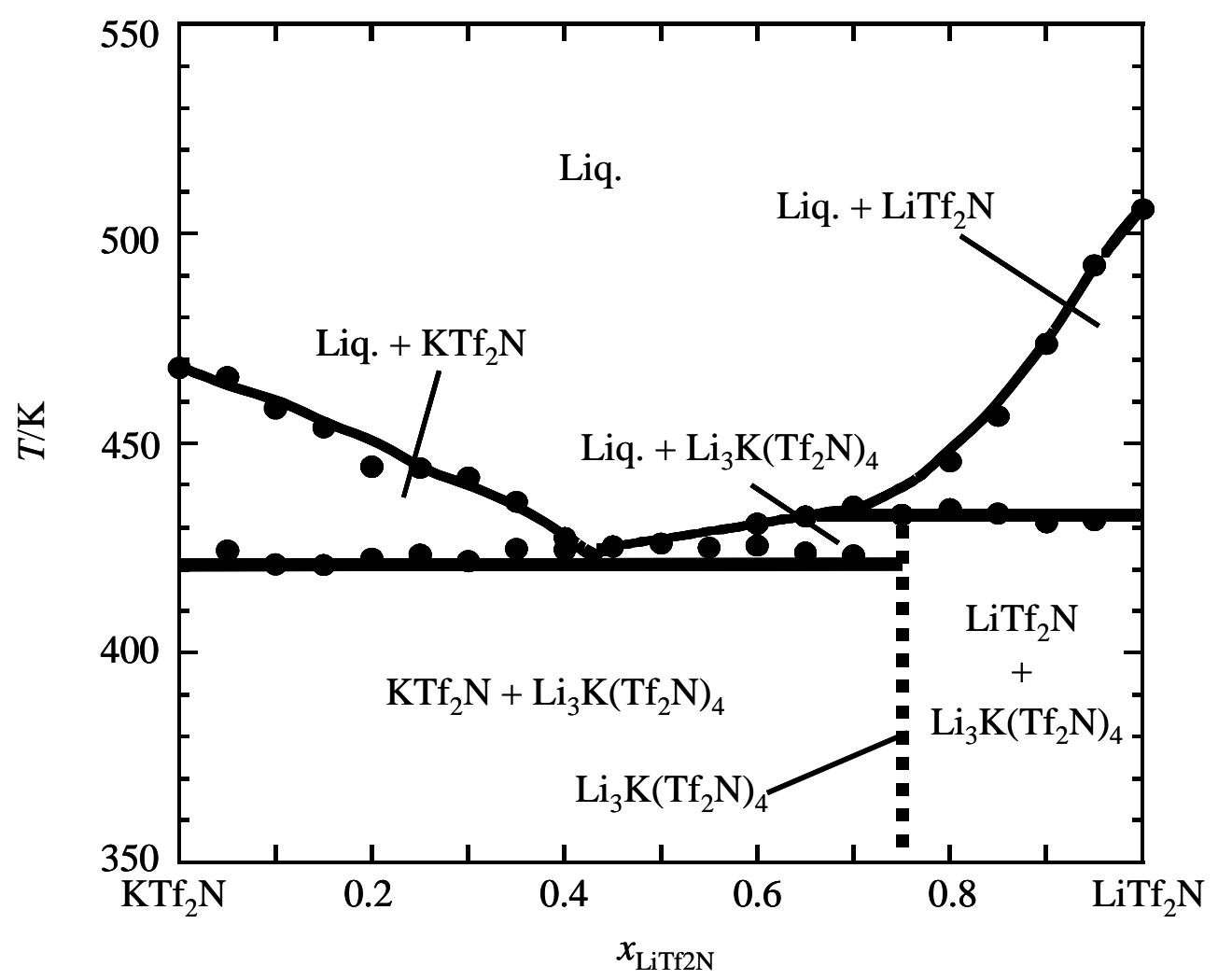

Figure 7. Phase diagram of $\operatorname{LiTf}_{2} \mathrm{~N}+\mathrm{KTf}_{2} \mathrm{~N}$. 


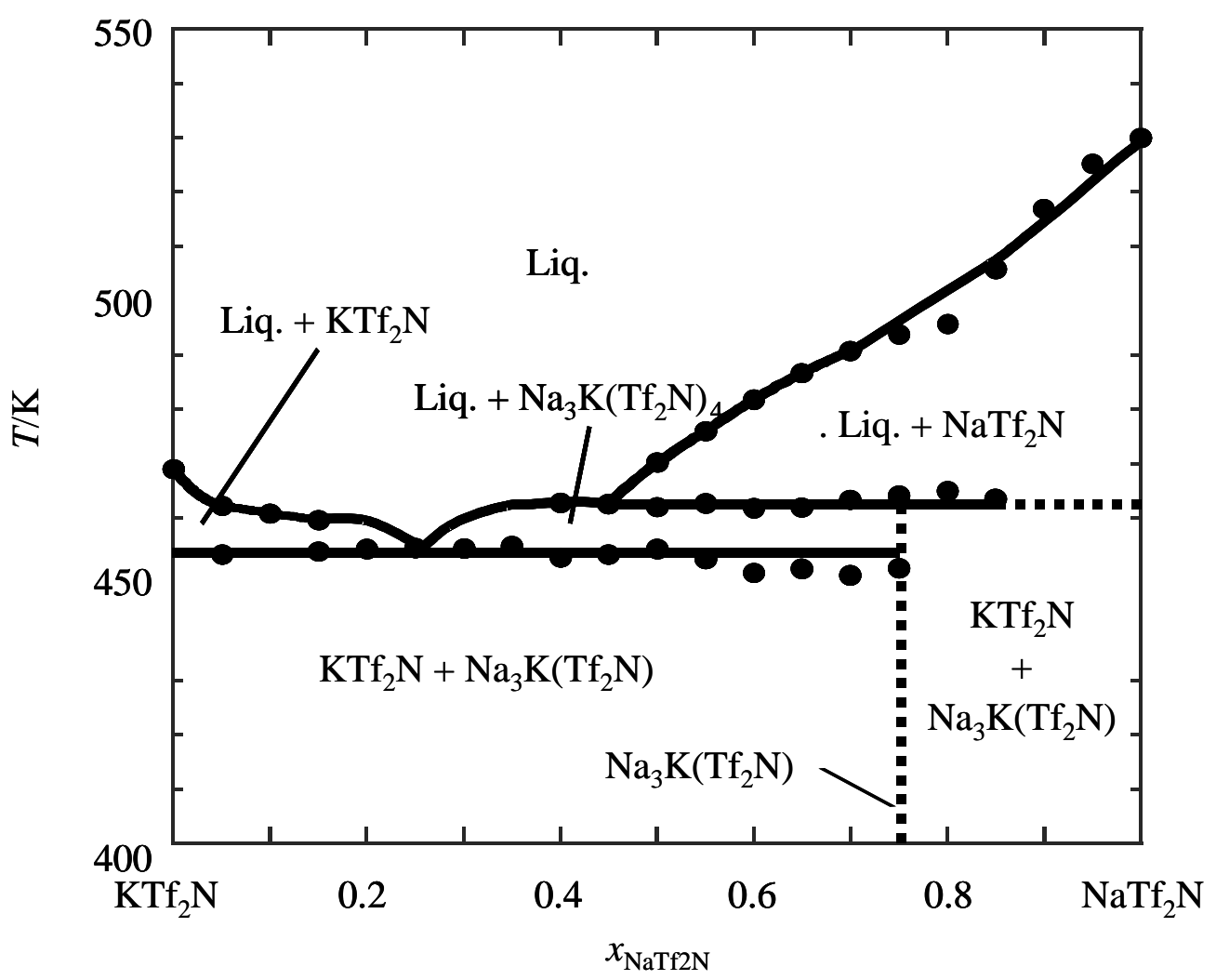

Figure 8. Phase diagram of $\mathrm{NaTf}_{2} \mathrm{~N}+\mathrm{KTf}_{2} \mathrm{~N}$. 


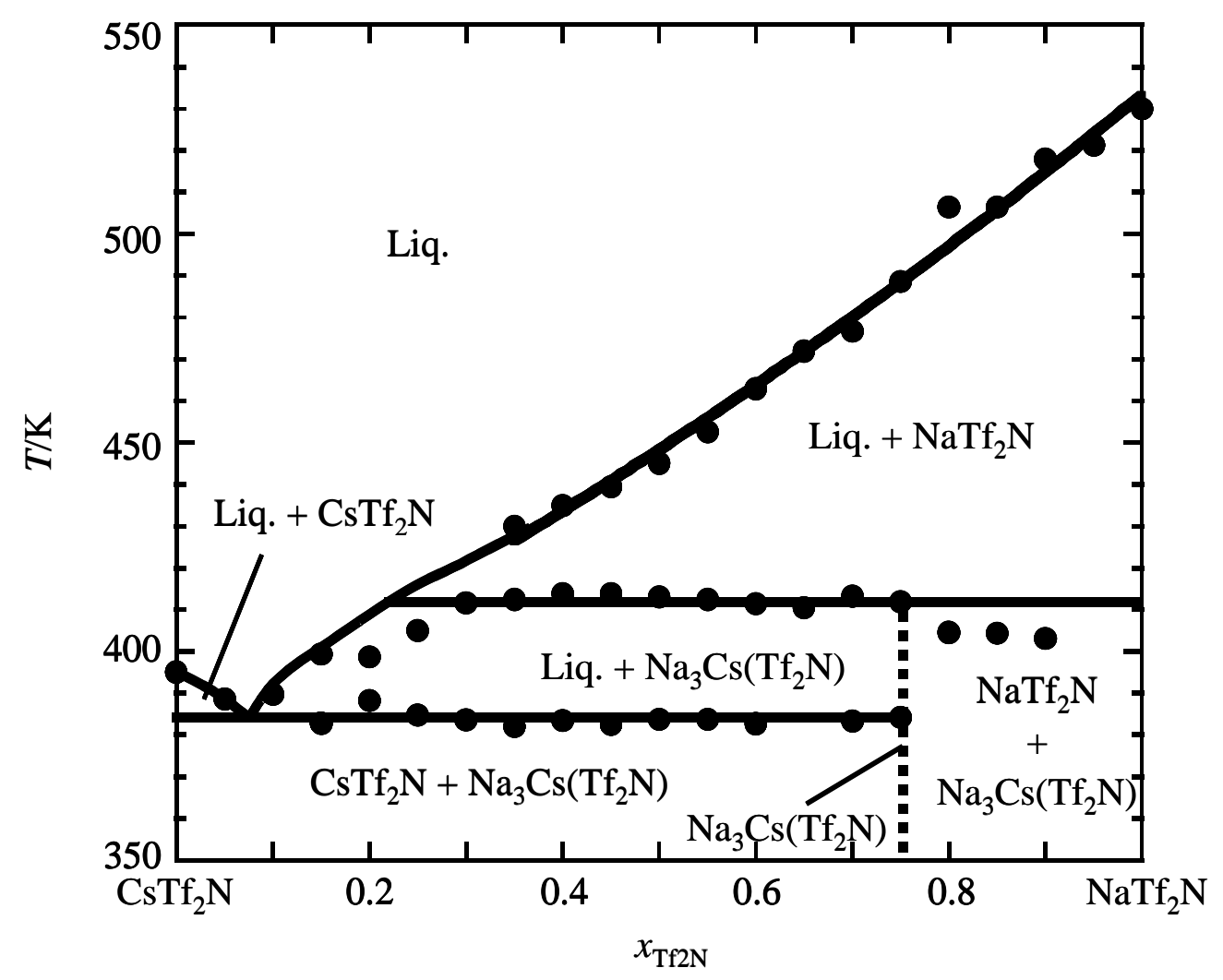

Figure 9. Phase diagram of $\mathrm{NaTf}_{2} \mathrm{~N}+\mathrm{CsTf}_{2} \mathrm{~N}$. 


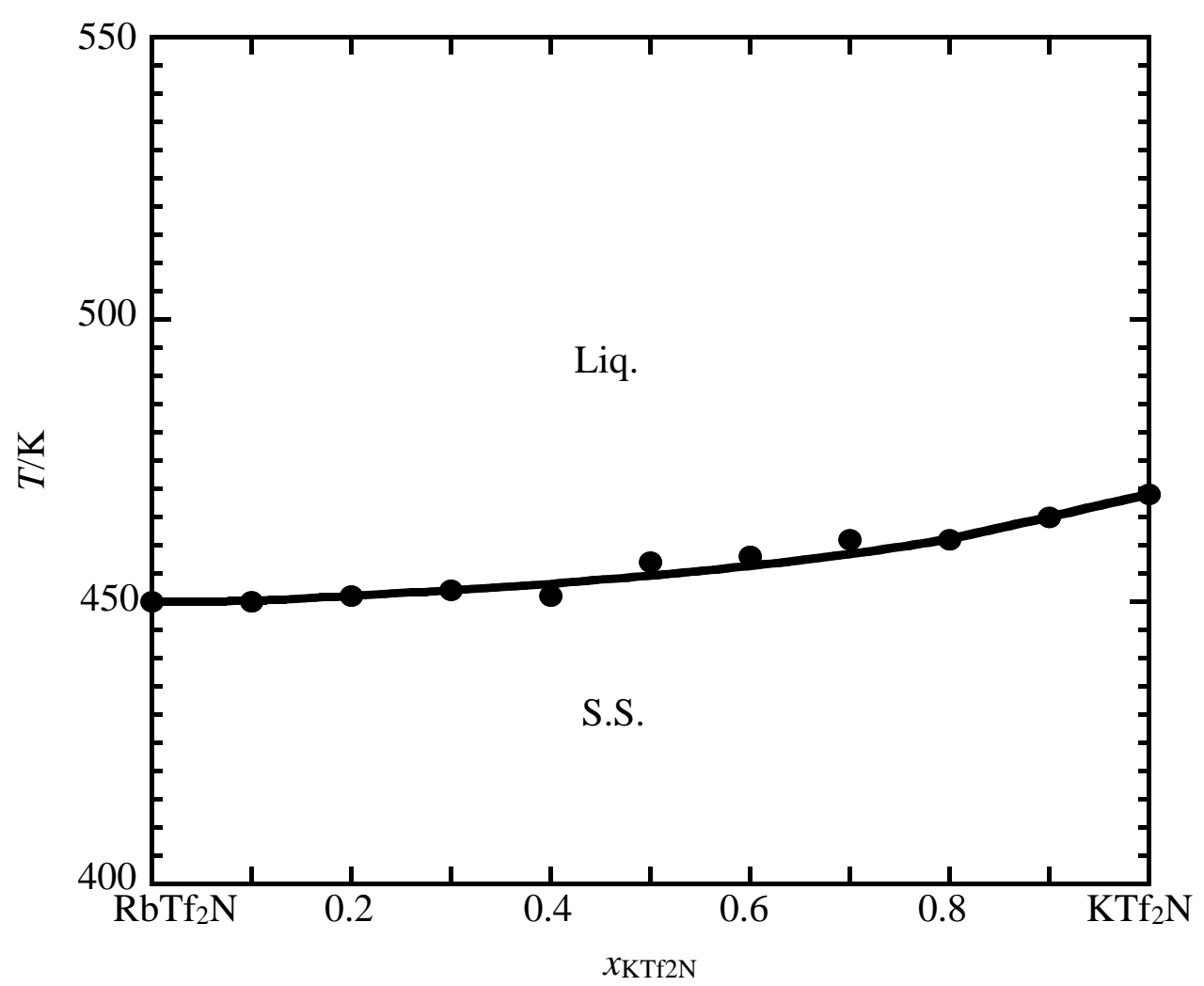

Figure 10. Phase diagram of $\mathrm{KTf}_{2} \mathrm{~N}+\mathrm{RbTf}_{2} \mathrm{~N}$. 


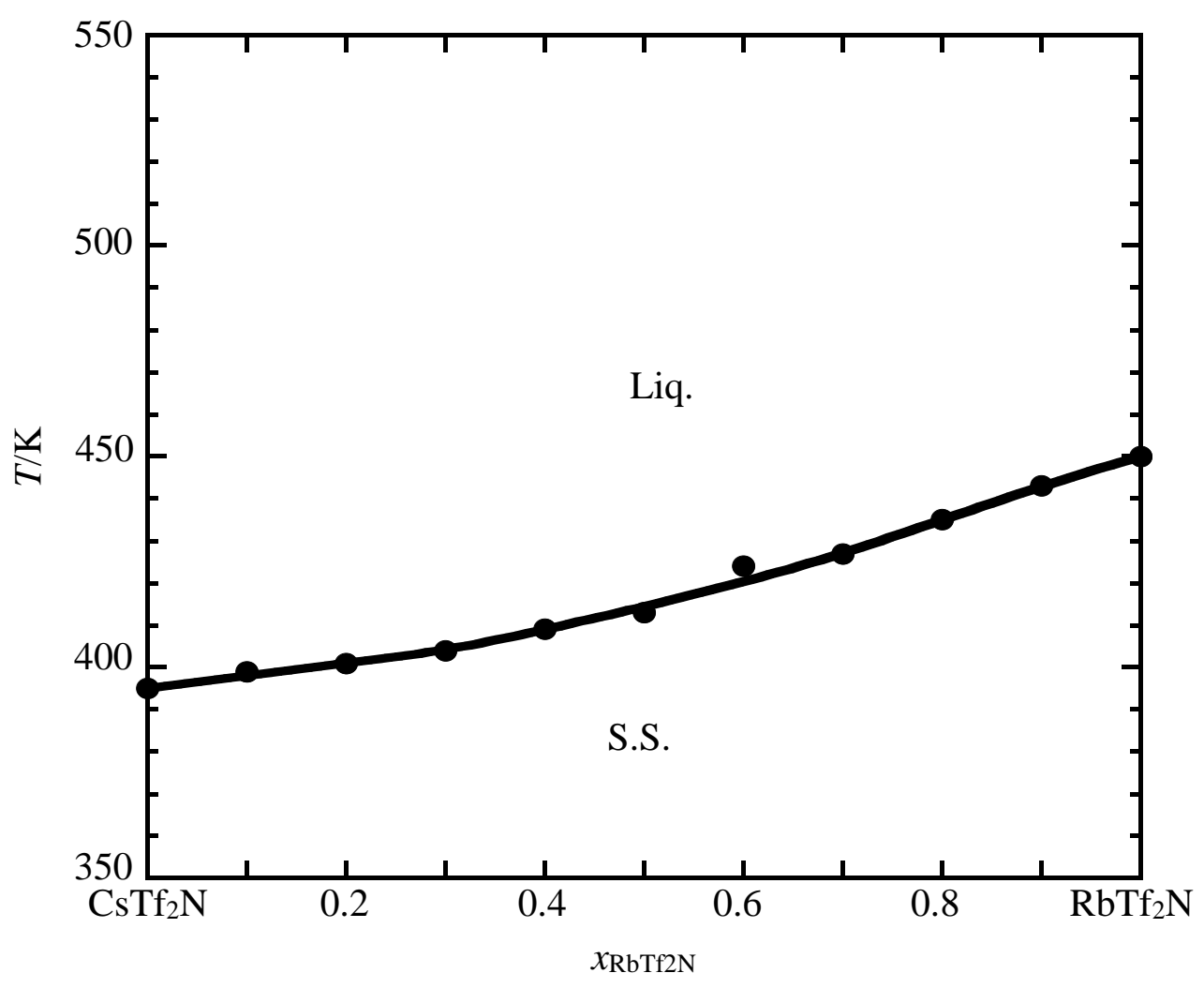

Figure 11. Phase diagram of $\mathrm{RbTf}_{2} \mathrm{~N}+\mathrm{CsTf}_{2} \mathrm{~N}$. 